Organization Science

Vol. 19, No. 2, March-April 2008, pp. 341-358

\title{
On the Problem of Participation in Strategy: A Critical Discursive Perspective
}

\author{
Saku Mantere \\ Hanken Swedish School of Economics and Business Administration, \\ Eero Vaara
}

Swedish School of Economics and Business Administration, FIN-00101, Helsinki, Finland, and École de Management de Lyon, 69132 Lyon Ecully Cedex, France, eero.vaara@hanken.fi 
We still know little of why strategy processes often involve participation problems. In this paper, we argue that this crucial issue is linked to fundamental assumptions about the nature of strategy work. Hence, we need to examine how strategy processes are typically made sense of and what roles are assigned to specific organizational members. For this purpose, we adopt a critical discursive perspective that allows us to discover how specific conceptions of strategy work are reproduced and legitimized in organizational strategizing. Our empirical analysis is based on an extensive research project on strategy work in 12 organizations. As a result of our analysis, we identify three central discourses that seem to be systematically associated with nonparticipatory approaches to strategy work: "mystification," "disciplining," and "technologization." However, we also distinguish three strategy discourses that promote participation: "self-actualization," "dialogization," and "concretization." Our analysis shows that strategy as practice involves alternative and even competing discourses that have fundamentally different kinds of implications for participation in strategy work. We argue from a critical perspective that it is important to be aware of the inherent problems associated with dominant discourses as well as to actively advance the use of alternative ones.

Key words: strategy; discourse; participation; critical management studies; subjectivity History: Published online in Articles in Advance January 7, 2008. 
Participation is a key issue in strategy research and practice. While there is no consensus on the degree to which organizational members should participate in strategy formulation, most scholars agree that a lack of participation easily leads to poorly developed strategies (Floyd and Wooldridge 2000), dissatisfaction among those who are excluded (Westley 1990), and consequent difficulties in implementation (Mintzberg 1994). A lack of inclusion has also been seen as a sign of organizational inequality (Knights and Morgan 1991) and, thus, a moral problem in its own right (Collins 1997).

While strategy studies have often touched upon participation (Westley 1990, Floyd and Wooldridge 2000, Balogun and Johnson 2004), we still know little about the reasons behind a lack of participation in strategy work. In this paper, we argue that this crucial issue is linked to fundamental assumptions about the nature of strategy work. Hence, we need to uncover how strategy processes are typically made sense of and what roles are assigned to specific organizational members. For this purpose, we adopt a critical organizational discursive perspective (Phillips and Hardy 2002, Mumby 2004, Fairclough 2005). In this view, "discourses" are linguistically mediated constructions of social reality. They are not mere representations of social reality but important means through which beliefs, values, and norms are reproduced and at times transformed in social life (Foucault 1994, van Dijk 1998, Fairclough 2003).

Our analysis builds on previous studies of the discursive aspects of strategy and strategizing (Knights and Morgan 1991, Barry and Elmes 1997, Hendry 2000). In line with these studies, we see "strategy discourse" as a complex set of meanings constituting this body of knowledge (Knights and Morgan 1991) and organizational praxis (Whittington 2006). Prior studies have provided key insights into why managerial hegemony and lack of participation easily prevail in strategy work (Knights and Morgan 1991; Samra-Fredericks 2003, 2005; Laine and Vaara 2007). In this paper, we extend this research by a systematic analysis of how discourses may impede or promote participation in strategy work. It is important to examine both aspects to fully understand the various ways in which participatory or nonparticipatory approaches are discursively constructed.

Our research questions are the following: What kinds of discourses impede participation in strategy processes? and What kinds of discourses can then promote more widespread participation? In our empirical analysis, we report findings from an extensive 
study of organizational strategizing in 12 professional organizations based in the Nordic countries. We distinguish three discourses that seem to systematically reproduce and legitimize nonparticipatory approaches: "mystification," “disciplining," and "technologization." However, we also identify three discourses that explicitly promote participation: "selfactualization," "dialogization," and "concretization." This analysis helps us to understand how nonparticipatory approaches are easily legitimized and naturalized in organizational discourse, and also how alternative discourses may be mobilized to promote participation.

We are not arguing that all participation problems are due to discourse (for a review of literature on participation, see Sagie and Koslowsky 2000). On the contrary, we see discourse as one part of the complex set of social practices constituting strategy as organizational praxis. However, we argue that discourses play a central role in the reproduction and legitimation of participatory or nonparticipatory conceptions of strategy. Discourses are thus an important part of organizational praxis that should be taken seriously if we want to better comprehend the problems and challenges around participation. Identifying widespread conceptions of strategy work and analyzing their implications for engagement is also the key to systematic development of more effective and inclusive practices in strategizing (Whittington 2006).

This paper continues as follows. We next provide a review of how participation has been examined in the strategy literature. We then outline our critical organizational discourse analysis perspective. This is followed by the description of our empirical analysis. The subsequent sections present and elaborate on the six discourses identified in our analysis. We conclude by summarizing the theoretical contributions, outlining suggestions for future research, and discussing the implications for managers as well as other actors in the strategy field.

\section{Participation in Strategy Research}

Classical strategy literature is based on a managerialist foundation. In the early work, strategy formulation was envisioned as the task of top management. Others were involved only in implementation. Thereafter, a large part of the strategy literature focused on 
finding effective ways of formulating strategies, as is the case in the planning and positioning literatures (for an overview, see Whittington 1993, Mintzberg et al. 1998). Participation was, however, treated as a nonissue.

This view was challenged when researchers started to pay attention to the social processes in which strategies are actually realized (Pettigrew 1973, 1992; Mintzberg 1978; Chakravarthy and Doz 1992). Scholars argued that planned or formulated strategies might be no more important than bottom-up (Burgelman 1983) or emergent (Mintzberg and Waters 1985) ones. According to this view, strategy is not only developed by top management but is also a venue where other actors play a key role (Burgelman 1983, Bourgeois and Brodwin 1984, Floyd and Lane 2000). It has been argued that nonsenior managers have a better understanding of what strategies are realistic (Mintzberg 1994), that the ideas of lower-level managers are key to organizational knowledge creation (Hart 1992, Floyd and Lane 2000, Floyd and Wooldridge 2000), and that these ideas help adapt organizational strategies to changing environments (Burgelman 1983, Bourgeois and Brodwin 1984, Noda and Bower 1996, Lovas and Ghoshal 2000). Furthermore, participation improves the implementation of strategic plans through increased commitment (Guth and MacMillan 1986, Korsgaard et al. 1995, Klein and Sorra 1996, Kim and Mauborgne 1998), integration of subunit goals (Ketokivi and Castañer 2004), and collective sensemaking (Gioia and Chittipeddi 1991, Gioia et al. 1994). Studies of the reasons behind a lack of participation have, however, been scarce. What we do know is that the environment affects participation. A stable environment leads to a more hierarchical administrative structure whereas a dynamic environment encourages middle management and personnel involvement (Miles et al. 1978, Floyd and Lane 2000). Participation has also been linked to organizational design and managerial implementation tactics that can either increase or limit engagement (Nutt 1987, 1989). Furthermore, inclusion is dependent on the social interaction between top managers and other organizational members (Westley 1990). For example, the way strategy conversations are set up has a crucial impact on middle managers' sense of inclusion (Westley 1990).

Recently, a new approach to strategy has emerged with a focus on social practice (Whittington 1996, 2006; Johnson et al. 2003; Balogun and Johnson 2004, 2005; 
Dougherty 2004; Jarzabkowski 2004, 2005; Mantere 2005; Jarzabkowski et al. 2007). This research stream shares many of the characteristics of the strategy process literature but seeks a better understanding of the microlevel processes and practices constituting strategy and strategizing. Strategic practices include administrative and episodic as well as discursive practices (Jarzabkowski 2005). From this perspective, discourses are firmly intertwined with the other social practices in strategy processes. Some practices enable participation and some constrain it. Analyses focusing on these practices have helped us to see the impact of specific social conditions and established organizational practices on how actors such as middle managers take part in strategy work (Balogun and Johnson 2004, 2005). However, to date, we lack studies concentrating on discursive practices impeding or promoting participation.

Parallel to these streams of research, we have seen the emergence of a literature concentrating on strategy discourse (e.g., Knights and Morgan 1991, Barry and Elmes 1997, Hendry 2000, Levy et al. 2003, Vaara et al. 2004). In a seminal analysis, Knights and Morgan (1991) examined strategy as a body of knowledge and analyzed the various kinds of power implications that the language of strategy has for organizations. Their analysis later inspired other theorists to examine strategy through a critical lens (Hendry 2000, Lilley 2001, Levy et al. 2003, Grandy and Mills 2004). Other studies then focused on the role of narratives in strategy processes in organizational contexts (Barry and Elmes 1997, Dunford and Jones 2000). Still others studied how specific discursive resources can be used for strategic purposes (Hardy et al. 2000, Maitlis and Lawrence 2003) and how strategies become legitimized and naturalized through the extensive use of particular discursive practices (Vaara et al. 2004). The analyses of Samra-Fredericks (2003, 2004, 2005) and Laine and Vaara (2007) in turn illustrated that conceptions about the roles and identities of organizational actors are easily reproduced in organizational interaction, often effectively impeding participation in strategy work.

This emergent literature holds great promise with respect to complex issues such as participation. However, most of the existing analyses have treated strategy simply as a hegemonic discourse without specifying the discursive practices that constrain or impede participation. For this purpose, we now focus on the very conceptions of strategy work that tend to either impede or promote organizational participation. Because these 
conceptions are mediated and reproduced in organizational discourse, we now outline a specific critical organizational discourse analysis perspective on strategy.

\section{A Critical Organizational Discourse Perspective}

There are many approaches to discourse analysis in general (van Dijk 1997) and organizational discourse analysis in particular (Alvesson and Kärreman 2000, Phillips and Hardy 2002, Grant et al. 2004, Hardy et al. 2004). Our analysis follows the critical tradition inspired by poststructuralist discourse analysis (Foucault 1994) as well as critical methodologies developed in applied linguistics (Fairclough and Wodak 1997, Wodak and Meyer 2002, Fairclough 2003). In recent years, organization scholars have applied these ideas in critical organizational discourse analyses (Phillips and Hardy 2002, Hardy and Phillips 2004, Mumby 2004, Fairclough 2005). This approach focuses on the discursive construction of social identities and power relations, which makes it particularly suitable for our analysis of participation in strategy and strategizing.

Central to our approach is a dualist view of discourse. Discourses are both socially conditioned and socially constitutive, that is, discourses are influenced by social conditions but also construct social reality (Giddens 1984, Fairclough 2003). It is this latter "constitutive" or "performative" effect of discourse that is central in our analysis. Accordingly, language does not merely reflects social reality but is the very means of constructing and reproducing the world as it is experienced. In our present context, strategy discourses not only mirror existing social and material practices but also reproduce and at times transform these practices (Fairclough 2003).

Unlike some more radical approaches, we share a view according to which not everything is reducible to discourse (Fairclough 2003, 2005). We maintain that discourses are always associated with other social and material practices. In the strategy domain, this means that discourses are but one part of the body of knowledge (Knights and Morgan 1991) and organizational praxis (Whittington 2006). We emphasize that the causal powers of discourse are important but that their concrete effects are mediated through cognition and material practices (van Dijk 1998, Fairclough 2005). This means that the concrete effects of strategy discourse are often subtle, difficult to detect, and often pass 
unnoticed in social life. Accordingly, we focus on particular effects of discourse: how they reproduce specific conceptions of strategy work and legitimize particular forms of participation (e.g., inclusion or exclusion).

In organizational contexts, Hardy and Phillips (2004) pointed out that discourses construct concepts, objects, and subject positions. Concepts are the means through which people give specific meaning to organizational phenomena such as strategy. These make up the vocabulary without which we could not make sense of such phenomena in a meaningful way. Discourses also construct objects, as they are involved in the legitimation and naturalization of specific ideas, such as the nature of strategy work. For instance, "visions," "missions," and specific "top-down" or "bottom-up" approaches are not only concepts but also have become naturalized parts of organizational life in contemporary organizations. Discourses also construct specific subject positions for social actors. These positions define the structure of rights for the actors involved_what they are expected, can, or can not do (e.g., Davies and Harré 1990). These positions are essential to understanding the agency and identity of specific organizational actors in strategy processes. These subject positions are thus crucial for comprehending how specific actors are supposed to or can participate in strategy work.

Discourses are easily reproduced in organizational interaction without a full understanding of their implications. In particular, as Knights and Morgan (1991) argued, strategy discourse has legitimized and naturalized managerialist, instrumentalist, and male-dominated conceptions of organizing. Rendering such problematic constructions visible can be seen as a fundamental challenge for critical organizational discourse analysis (Phillips and Hardy 2002, Mumby 2004, Fairclough 2005). However, this does not imply the absence of other, even emancipatory, discourses around strategy. On the contrary, we argue that one can often distinguish alternative discourses that provide very different means for making sense of and giving sense to strategy and the roles that social actors are expected to play. In fact, these discourses can coexist in a dialectical relation where more dominant discourses are challenged by alternative ones (e.g., Mumby 2004, 2005).

Consequently, an essential part of understanding the reasons for lack of participation in strategy processes is to examine the discourses through which 
organizational actors make sense of and give sense to strategy and strategizing. For our purposes, it is important to concentrate on those discursive practices that seem to either constrain or enable participation. This leads us to formulate the following two research questions for our empirical analysis:

- What kinds of discourses impede participation in strategy processes?

- What kinds of discourses can promote more widespread participation?

\section{Methodology}

Our analysis is based on an extensive research project focusing on the social organization of strategy work in 12 organizations, operating mainly in Finland and other Nordic countries. They are professional service organizations in which many employees arguably play "strategic" roles vis-à-vis other stakeholders. The organizations include eight companies from the finance, insurance, retail, and telecommunications sectors, and four government or municipal organizations.

Our empirical material consists of interviews, documents, and other data gathered in interaction with the representatives of these organizations. Interviews with 301 individuals form the core of this empirical material. A key idea was to include people from different levels of organizational hierarchy, with a special emphasis on nonsenior managers. Accordingly, the interviewees include 39 top managers, 83 middle managers, and 179 operating personnel. One hundred and thirty five interviewees had a university education and 121 had a vocational one. One hundred and fifty were men and 151 women (see Table 1). 
Table 1. Interviews in case organizations

\begin{tabular}{|c|c|c|c|c|c|c|c|c|c|c|c|c|c|}
\hline Organization & 1 & 2 & 3 & 4 & 5 & 6 & 7 & 8 & 9 & 10 & 11 & 12 & Total \\
\hline Industry & \multicolumn{3}{|c|}{ Telecommunications } & \multicolumn{4}{|c|}{ Finance } & Retail & \multicolumn{4}{|c|}{ Government/municipal } & \\
\hline Top managers & 2 & 2 & 3 & 2 & 5 & 3 & 3 & 3 & 5 & 3 & 4 & 4 & 39 \\
\hline Middle managers & 7 & 6 & 6 & 9 & 11 & 5 & 6 & 12 & 5 & 6 & 5 & 5 & 83 \\
\hline Operating personnel & 16 & 17 & 16 & 14 & 8 & 17 & 16 & 12 & 15 & 16 & 16 & 16 & 179 \\
\hline
\end{tabular}


All interviews followed a semistructured interview outline. The main idea was to follow a "storytelling" approach, that is, to let the interviewee describe as freely as possible his/her views on strategy (for a similar approach, see Vaara 2002). However, there were specific questions that directed the interviewees' attention to the key themes of strategy processes and strategizing activities. The questions in the outline focused on the following:

- The interviewee's role in the strategy process and the role of strategy in the interviewee's daily work (e.g., How do you participate in your organization's strategy process?).

- The interviewee's conceptions of strategy in general (e.g., What do you understand by the term "strategy"?).

- The interviewee's perception of organizational practices in implementing strategy and their effectiveness (e.g., What kinds of practices are involved in the communication of organizational strategy? Do they work?).

- The interviewee's working environment and the impact of strategy in it (e.g., Have there been changes in your work lately? What kinds of changes?).

The interviews were recorded with the approval of the interviewees and transcribed verbatim in the language of the interview. As a rule, the interview language was Finnish, although there were a few exceptions where English was used.

A significant amount of documentary data was collected, including published material (e.g., annual reports and internal bulletins) and confidential material about their strategy processes (e.g., presentations, process diagrams, and top management team memos). Two workshops were organized for all 12 cases. The first workshops, conducted before the interviews, focused on the organization's current strategy and the key characteristics of its strategy process. The second workshops, conducted after the interviews, then concentrated on the specific problems and challenges encountered in their strategy work. Notes were taken in these meetings and follow-up documents were also produced. In a few cases, the second workshops led to specific development projects where problems associated with strategy work were discussed in great detail. In addition, 
there were numerous other formal and informal meetings between the researchers and the organizations. These multiple sources of empirical material were useful for data triangulation (Denzin 1970, Jick 1979). In particular, the documentary data and the frequent encounters with the organizational members helped us to put the interview material in a wider context; we were able to examine what was said in the interviews and distinguish essential characteristics of the strategy discourses in these particular organizations.

As is usually the case in this field, our analysis followed an inductive logic (Phillips and Hardy 2002, Wodak and Meyer 2002). This meant an exploratory approach vis-à-vis our data and an attempt to continuously structure the data to form a "grounded" understanding of the phenomena in question. Such a grounded approach is useful for producing "mid-range theory," high in accuracy and specificity but lower in generality and simplicity (Langley 1999). As this kind of analysis also involves constant input from theory, it may more accurately be described as "abductive," where "a constant movement back and forth between theory and empirical data is necessary" (Wodak 2004, p. 200).

In practice, this analysis proceeded through four stages. The first stage focused on involvement in strategy work. Based on all the interview and documentary material, we mapped out the key characteristics of the strategy processes in all 12 organizations. We also examined each individual's (301) willingness and ability to engage in strategy processes. This involved an external evaluator as well as validation by representatives of these organizations in the workshops (for more details, see Mantere 2003). This analysis resulted in case-specific descriptions, the summaries of which are reported in Table 2. These findings also led us to examine more closely how specific social practices in general and discourses in particular may impede or promote participation.

In the second stage, we examined case-specific discourses. We concentrated on how strategy processes were understood and which roles organizational members were assigned in these processes. We closely analyzed the interview texts as well as other material, focusing on characteristic linguistic expressions: characteristic metaphors of strategy, identity constructions (e.g., "us" versus "them"), and specific modalities (ways of commitment expressed in texts, e.g., necessity and obligation). For example, in Organization 1, we observed that strategy was characteristically portrayed as a secretive 
top management activity. Its linguistic expressions included religious language where, for instance, "missions" and "visions" played an accentuated role. Accordingly, strategy was frequently conceptualized as something "preached" by top management, then to be "given" to and "followed" by other organizational members. Usually, these texts involved few degrees of freedom: This kind of process was seen as a necessity. However, rather than merely examining the interview or documentary texts, we also analyzed how discourses were connected to other social practices within our case organizations. For example, in Organization 1, strategy presentations, process diagrams, internal bulletins, and memos showed how discourse use was closely associated with practices such as organizing closed sessions for top managers as well as withholding information from other organization members. In this way, we could focus on those discourses that were an important part of the organizational praxis impeding participation.

In the third stage, we concentrated on discourses that seemed to be systematically associated with participation or a lack of participation across the cases. We coded our interview material accordingly and examined patterns across cases. This phase of research involved not only empirical analysis but also going back to the specific theoretical ideas of Foucault (1994) and Fairclough (2003), in particular. In this analysis, we focused on "performative" discourses, that is, discourses that have clear effects in terms of reproducing and legitimating specific conception of strategy work and modes of participation. We focused first on discourses associated with a lack of participation. This led us to distinguish "mystification," "disciplining," and "technologization" as particularly central nonparticipatory discourses. We next examined discourses that seemed to systematically promote participation. We focused on "self-actualization," "dialogization," and "concretization" as particularly salient examples of such discourses. For each case, we then completed the discursive mapping by examining which of these six discourses played a central role and how they related to each other. See Table 2 for case-specific examples and Table 3 for a summary of the main characteristics of these discourses.

In the fourth and final stage, we focused more closely on these six discourses. As is usually the case in discourse analysis, we identified and analyzed specific examples in more detail to better understand how particular conceptions of strategy work and the role 
of specific actors in it were discursively constructed and legitimized (Fairclough 2003). In this analysis, we were not looking at the most colorful or entertaining examples, but for typical examples of discourses reproducing and legitimating participatory or nonparticipatory conceptions of strategy work in our case organizations. In this way, we tried to avoid the "anecdotalism" that is often a problem for qualitative analysis (Silverman 2000).

Discourses Impeding and Promoting Participation

Table 2 summarizes our findings. In general, mystification, disciplining, and technologization were systematically associated with nonparticipatory approaches to strategy work. Self-actualization, dialogization, and concretization discourses in turn tended to promote participation. It should be emphasized that this is an analytical distinction and that in several organizations these discourses coexist and overlap. 
Table 2. Discursive practices impeding or promoting participation in the case organizations

\begin{tabular}{|c|c|c|c|}
\hline $\begin{array}{l}\text { Org } \\
\text {. }\end{array}$ & Participation & Discourses impeding participation & Discourses promoting participation \\
\hline 1 & $\begin{array}{l}\text { A top-down driven process. Middle managers } \\
\text { and operating personnel generally feel content } \\
\text { and sufficiently "informed" of strategy. Some } \\
\text { express frustration not to be more involved. }\end{array}$ & $\begin{array}{l}\text { Mystification: Strategy as a "destiny" "preached" by } \\
\text { top managers. Operating personnel mainly accept this } \\
\text { as a given, middle management feel they have to "do } \\
\text { the dirty work." }\end{array}$ & $\begin{array}{l}\text { Concretization: Clear rules, measures } \\
\text { and detailed procedures called for. }\end{array}$ \\
\hline 2 & $\begin{array}{l}\text { Middle managers and personnel are regarded as } \\
\text { unimportant in strategy work. Some of them are } \\
\text { frustrated when trying to gain access to strategy, } \\
\text { some are altogether cynical. }\end{array}$ & $\begin{array}{l}\text { Mystification: Strategy portrayed as a "direction" set } \\
\text { exclusively by top management. Personnel denied } \\
\text { access to strategy documents. } \\
\text { Disciplining: Military terms such as "troop } \\
\text { deployment" used to naturalize top down approach. }\end{array}$ & $\begin{array}{l}\text { Concretization: Transparent rules } \\
\text { called for. }\end{array}$ \\
\hline 3 & $\begin{array}{l}\text { A stark division between top management and } \\
\text { others. Middle managers are struggling to } \\
\text { participate. Some personnel members cynical of } \\
\text { strategy. Others lament top management's lack } \\
\text { of interest in communication. }\end{array}$ & $\begin{array}{l}\text { Mystification: Strategy portrayed as a "direction" set } \\
\text { by the top management exclusively. } \\
\text { Technologization: Top management control } \\
\text { reproduced through an extensive use of } \\
\text { "measurement instruments." }\end{array}$ & $\begin{array}{l}\text { Self-actualization: Critical thinking } \\
\text { and genuine participation called for. }\end{array}$ \\
\hline 4 & $\begin{array}{l}\text { Everybody is willing to participate in strategy } \\
\text { work. Many employees are happy to be involved } \\
\text { in team level planning; others crave for a larger } \\
\text { role. Participation is widely recognized as } \\
\text { necessary and legitimate in strategizing. }\end{array}$ & $\begin{array}{l}\text { Technologization: Strategy as "given" through top } \\
\text { management's control system. This discourse is not } \\
\text { dominant, however. }\end{array}$ & $\begin{array}{l}\text { Dialogization: Strategic planning as a } \\
\text { dialectic between top-down strategic } \\
\text { plans and bottom-up team work and } \\
\text { suggestions. } \\
\text { Concretization: The role of specific } \\
\text { rules and procedures emphasized and } \\
\text { legitimated. }\end{array}$ \\
\hline 5 & $\begin{array}{l}\text { Strategy has been externally imposed by } \\
\text { political decision makers and ability to } \\
\text { participate is regarded as poor. Ambiguities and } \\
\text { differences of opinion exist regarding the } \\
\text { meaning of strategy. }\end{array}$ & $\begin{array}{l}\text { Mystification: Strategy discussed in abstract terms, } \\
\text { e.g. as a "path toward an organizational vision." } \\
\text { Abstraction tends to mask ambiguity. } \\
\text { Disciplining: There are struggles between the } \\
\text { "central command" of the headquarters and the } \\
\text { "military campaigns" of field offices. On the whole, } \\
\text { top-down control is naturalized between leaders and } \\
\text { followers. }\end{array}$ & $\begin{array}{l}\text { Concretization: The "dismantling" of } \\
\text { strategy into operationalized targets } \\
\text { seen as desired as it would enable the } \\
\text { "aligning of activities." }\end{array}$ \\
\hline
\end{tabular}


\begin{tabular}{|l|l}
\hline 6 & Management dominates strategy work. Some
\end{tabular} teams have planning processes which create a sense of inclusion for personnel as well.

\begin{tabular}{|l|l}
\hline 7 & Management-driven strategy process. Many
\end{tabular} people are used to this approach. Some organizational members cynical of strategy work. Strategy language regarded as complicated, scorecard measures impractical.

8 Personnel members are excluded from the strategy process. Some organizational members regard obedience as natural, others are cynical.

9 Top management in control. Most middle management and personnel members accept a limited role in strategizing. Others are seeking ways to participate.

10 Both top and middle management involved in strategizing. However, tensions exist between specific groups. Most personnel members are unable or unwilling to participate.

\section{Mystification: Strategy portrayed in official} documents as a "shared voyage" of all organizational members, yet collectiveness appears to be illusory.

Disciplining: The organization portrayed as an educational institution with "classroom rules" and "timetables." Managers seen as "teachers" responsible of making "good citizens" of their pupils.

Technologization: Balanced scorecard used to extend a quantification and measurement discourse over all operational activities.

Mystification: Strategy as a "path" or "will" set by the top management, which is "given" to the lower echelons.

Disciplining: Military terms such as "troop deployment" used to naturalize the top down approach.

Disciplining: Strategy is portrayed in terms of ongoing hostilities towards an external enemy, calling for obedience with regard to official policy. Punishment for non-compliance is normalized.

Technologization: Business concept explicated to the very last detail, eliminating "the need" for any interpretation. Actors portrayed as "links in the chain."

Disciplining: Strategic leadership regarded in pedagogical terms, as "providing an upbringing" to the personnel.

Mystification: Strategy portrayed as "fate," which "steers" the activities of organizational members.

Disciplining: Military language such as "troop deployment" is used by top managers to naturalize the "steering" of activities. In general, top-down control is naturalized between leaders and followers.
Concretization:_Some teams view strategic planning as a collective, yet very arduous process of "crafting," "filing" or "constructing."

No major examples found.

No major examples found.

Dialogization: Bottom-up planning in teams acknowledged as a part of the strategy process

No major examples found. 


\begin{tabular}{|c|c|c|c|}
\hline 11 & $\begin{array}{l}\text { Ability to participate well established at all } \\
\text { organizational levels. }\end{array}$ & No major examples found. & $\begin{array}{l}\text { Self-actualization: An emphasis on a } \\
\text { constant search for meaning in work } \\
\text { (e.g. "collective mapping" or "critical } \\
\text { seeking"). }\end{array}$ \\
\hline 12 & $\begin{array}{l}\text { Most members willing and able to participate in } \\
\text { strategy work at all organizational levels. } \\
\text { Professional identity strongly present in } \\
\text { participation in strategy work. }\end{array}$ & $\begin{array}{l}\text { Technologization: Tendencies to treat strategy as } \\
\text { "given" through top management's control system. } \\
\text { This discourse is not dominant, however. }\end{array}$ & $\begin{array}{l}\text { Concretization: Strategy is seen to } \\
\text { provide "tools" for practical problem } \\
\text { solving. } \\
\text { Self-actualization: Strategy as a } \\
\text { shared sense of collective direction, } \\
\text { connected to professional identity. }\end{array}$ \\
\hline
\end{tabular}




\section{Discourses Impeding Participation}

Mystification. Strategy discourses tend to endow strategy work with special status (Knights and Morgan 1991, Hendry 2000). This can, however, lead to the problematic tendency of "mystification": the obfuscation of the activity so that its meaning is only open to privileged actors (e.g., Marx 1999, Fairclough 2003). This was the case in several organizations where strategy was understood as a secretive activity, led by top management, in which others could only participate in very limited terms. This was most clearly illustrated in Organizations 1 and 2 (see Vignettes 1 and 2 below) (refer also to Table 2).

Vignette 1. Grand visions, subjugation, and resistance.

In Organization 1, a telecommunications group, top management had traditionally pursued a top-down approach to strategy. An essential part of their process was to use grandiose, emotionally-laden rhetoric to set the "direction" for the whole group. This is how a top management team member described their approach:

[Strategy is] a way to arrive at objectives: first a vision, then for this vision we [top management] set objectives. How to arrive at objectives is when people put their brain, their heart, their hands, and their guts into one focus topic of strategy [implementation by organization]. They [organization] put this strategy into motion. (TMT member)

This comment reflects and reproduces the classical top-down view of strategy: Top management ("we" in he quotation) is in charge of strategy and organization "they" in the quotation) of its implementation. This view was institutionalized in official strategy process documents where "vision" was defined as the first step of the process and "sharing" as the last one. Only this "sharing" stage involved the participation of those outside of top management. Furthermore, this sharing implied one-way communication with no opportunity to question the views of top management.

Most middle managers and operating personnel seemed to be satisfied with this approach to strategy. On the whole, they tended to consider strategy as a legitimate top 
management-led activity defining the overall purpose of the organization. This was regarded as top management's "natural responsibility," and they were seen as possessing "superior knowledge." Illustratively, a manufacturing specialist described the organizational strategy process as a "waterfall," cascading from the top of the organization downward. Another manager described his role as follows:

Do I have it in me to participate in strategy making? No, I doubt it. For that you need a lot more experience, to be able to understand our whole industry and how it will develop. I do not have the experience to build such a bird's eye view. (logistics manager)

However, some middle managers felt that their position was very difficult because they could not participate in strategy formulation. They saw that they were left to do the "dirty work" while their superiors spoke of "grand things." This is how a middle manager explained his frustration:

Our strategy? It's to do our work to the best of our ability. You want an official answer? Sure, I'll give you one_takes out a card summarizing the official strategy in a few bullet points and hands it to the interviewer. But the real question is how we make gold out of shit. _factory manager_

\section{Vignette 2. Strategy as the order of things.}

In Organization 2, a large telecommunications firm, strategy making was seen as a "serious business," open only to a selected group of people. Well-known international consultants were used to facilitate the top management team in its strategy work. Access to strategy documentation, even to those documents found in the company intranet, was limited to people at the top managerial echelons. In their discourse, strategy was typically envisioned as a "direction" set by the top management team, aided by the consultants. A top management team member explained this as follows:

This is the order of things in my mind: First top management defines a vision, a desired end state, which is then pursued. Strategy is then formed into a kind of a set of operative activities leading to the desired end state. (TMT member) 
The organization consisted of a large workforce of expert personnel. While some of them had internalized the top-down approach to strategy, others were frustrated. Some of them openly questioned the nonparticipatory nature of strategy work.

Our information policy [withholding information] is almost hysterical. I can not say that I know these [strategy documents] very well. I got promoted recently and only then was I allowed access to these documents in the intranet. You don't get much information if you don't have sufficient rank and insignia ... This was the first time I got to know where we are going as an organization. (marketing manager)

To channel their frustration, some organizational members used cynicism to ridicule the organization's strategy work:

I used to work in a smaller firm where people could participate in strategic planning. In my new role in this large firm, I have had to teach myself that planning is none of my business. They want to maintain a very small inner circle in this organization, and once a year, in a huge spectacle, to present it all in one spectacular slide. (sales support manager)

The notion of an "inner circle" is an illustrative example of assigning specific power to a few "enlightened" leaders: It is their responsibility to produce the strategies. As the interviewee explains, the end result ("one spectacular slide") was then communicated to others who were not able to challenge the statements, not even given access to the reasoning behind the official strategy statements.

These first two vignettes illustrate more widely observed tendencies in organizations where mystification was encountered. Mystification tended to reproduce an image of top management-driven strategy work where the actual planning was conducted in small groups, often in secrecy. In the strategy documents as well as the interviews, "visions" or "missions" were given a special status as cornerstones of strategy. They were seen as something "defined" by or "arriving" from top management, not to be questioned or challenged by others.

Mystification created specific subject positions for the people involved in strategy processes. Those in charge were given a special authority position, resembling what 
Foucault has called "pastoral power" (Foucault 1982, pp. 213-215). In fact, some top managers in these organizations explicitly portrayed themselves as "preaching the gospel" in the sense of trying to convince others to follow their ideas. Sometimes, the mystifying discourse seemed to serve primarily as an attempt to strengthen the power position of top managers. This could, as in Vignette 1, lead to strategy work that was "grandiose" but "empty of real content."

For the others, the mystification of strategy work implied a strong expectation of compliance. As in religious movements, the role of other was to internalize the "visions" or "missions" as a "higher purpose" without critical reflection on these predefined goals (for analogous findings, see Westley 1990). In the organizations characterized by mystification, this often resulted in selfsubjugation, that is, in acceptance of this state of affairs as normal. For example, this was the case with the operating personnel in Organization 1 (Vignette 1). Such self-subjugation often involved a sense of not being adequately informed or qualified to be engaged in strategy work.

However, our case material also includes many examples where the middle managers or operating personnel resisted mystification. Frequently, this involved cynical comments about the strategy process of the organization. This was particularly salient in Organizations 1 and 2 (Vignettes 1 and 2), for example, in the factory manager's cynical attitude toward official strategy (Vignette 1) or in the sales manager's sarcastic comments as to how to "teach herself" that strategy is "none of her business" (Vignette 2). Such resistance undermined the legitimacy of top management control but also questioned the very meaning of conventional strategy work. Importantly, such cynicism was often closely associated with distancing oneself from strategy work. In this sense, this resistance actually reproduced nonparticipation in these organizations.

Disciplining. Discipline denotes the ever-present structures and techniques that govern individuals (Foucault 1994). Importantly, discipline can be both facilitative and constraining. In strategy work, some degree of discipline is probably always needed for meaningful concerted action (see our discussion on the discourses promoting participation). However, here we focus on how discipline may impede participation in strategy work. We define "disciplining" as discursive construction of organizational 
hierarchies and command structures that impede participation in strategy processes. Our material includes many examples of disciplining, but Organizations 8 and 9 serve as particularly illustrative cases (see Vignettes 3 and 4).

\section{Vignette 3. Discipline and punishment.}

In Organization 8 , a retail chain, the strategy process was conceptualized in military and technological vocabulary. Participation in strategy involved top and middle management, leaving the operational personnel to follow rules and procedures to the letter. A top manager described their approach as follows:

I was the one who decided the objectives and the means for reaching them. What would happen if nobody made these decisions? I mean that these [strategic decisions] are not collective. Somebody just has to make the decisions and get the others to follow. And what you need is to get the men in the field to follow you. (top manager)

It was typical in this organization's strategy discourse to emphasize the ideal of top-down control (e.g., "not collective" and "men in the field," above). This was the case also further down in the organizational hierarchy. The following is a typical example:

Our store is one cog in a much larger machine. The sales clerks need to understand their own roles as a part of that cog. Building this understanding constitutes one of my most central tasks, that is, to start from the department managers, to explain to them what this means. What our objectives are. How the objectives link with the strategy of the chain. (epartment store manager)

As this comment illustrates, personnel were frequently portrayed as objects (here, "cogs in a much larger machine") rather than subjects that could actively participate in decision making. Interestingly, explicit sanctions played a central role in this discourse as in the following quotes: 
My role is also to be a punisher. When you have reached a limit in understanding peoples' problems, you need to draw certain conclusions ... whether this one needs more education or something. [middle manager] If you have given a person all that you can and still nothing happens, then you need to cut this person's rations. (middle manager)

The operating personnel were involved in this discourse in various ways. Many were used to this approach and in the interviews reproduced ideas such as "you need to have some discipline" and "everybody simply can not play solo." However, others were frustrated with their inability to participate in decision making concerning central questions. Some interviewees had become almost paranoid:

There are cameras everywhere. That's why I asked you if this interview was confidential ... I don't like to be watched all the time. (sales clerk)

\section{Vignette 4. Strategy as schoolwork.}

The leaders of Organization 9, a governmental office, had adopted elements from educational discourse into their strategy talk. Top managers liked to portray their roles as "teachers" or "parents," responsible for the wellbeing and "upbringing" of their subordinates:

Generally speaking, my role in strategy is to be the shepherd. (CEO)

Interestingly, the term "participation" had become an essential part of this discourse. However, it was constructed as an obligation, as a part of the educational process, as the following comment illustrates:

Participation in the discussion of_our unit's_strategy is not voluntary. If you are not present in these discussions, you need to have a good reason. (TMT member)

Overall, Organization 9 resembled an educational institution, with clearly defined roles for teachers and students. In fact, self-assessments, development discussions, and organizational-level evaluations were seen as key parts of the annual strategy process. Interestingly, the personnel of Organization 9 had largely internalized this discourse and 
thus adopted the roles of students to be educated. The following is a typical comment from an office clerk:

[Implementing strategic objectives] is little bit like selfevaluation at school. If you have learned to do it from day one, as a student in the first grade, you also know how to do it on the job. (office clerk)

These vignettes illustrate typical disciplining tendencies. As Vignette 3 shows, strategy was often linked to explicit hierarchical language drawing from military discourse. This is not surprising, as warfare is the etymological origin of strategy discourse (Knights and Morgan 1991). Notions of war and battle were frequent in our data, as exemplified by "winning battles" or "making field decisions." In addition to military discourse, educational language was used in disciplining as is shown in Vignette 4. Organizational members were here seen as inmates in a disciplining institution (for similar findings, see Oakes et al. 1998).

Disciplining means the imposition of clear-cut managerial authority. In this discourse, top management was portrayed as leaders who are responsible for making critical decisions for the whole organization. This involved strengthening the power position of top management in general but often the heroification of specific persons as well. For the other organizational members, disciplining implied a subordinate role. Interestingly, an inherent part of this discourse was punishment, as expressed vividly in Vignette 3.

In these organizations, it was very common for middle managers and operating personnel to have internalized this discourse. This was shown in frequent selfsubjugating comments in the interviews as well as in our workshops and informal encounters. The comment concerning self-assessment in Vignette 4 is a typical example. However, as in the case of mystification, some organizational members had grown skeptical toward the disciplining discourse and practice. Some of them even expressed paranoid sentiments, as the comment on constant surveillance at the end of Vignette 3 demonstrates.

Technologization. Strategy is often linked to specific systems and technologies. While such technologies may aid participation in some cases, we will focus on the constraining 
aspects. Drawing on Heidegger (1977) and Foucault (1977), we see "technologization" as a discourse that tends to impede participation by imposing a technological system to govern the activities of individuals. Traces of technologization were already present in the "cogs in the machine" metaphor in Vignette 4. Organization 7, however, serves as a particularly illuminative example (Vignette 5).

\section{Vignette 5. Measuring performance.}

Organization 7, an insurance firm, had recently adopted the "balanced scorecard" as the vehicle for its strategy formulation and implementation. This system was used at all levels of the organization, from top management team strategy work to individual-level target-setting discussions. Members of top management were by and large satisfied with this approach since it provided a system that was more easily controllable than their previous less-structured practices in strategic planning.

For me, strategy quite simply means that we make sure that measures such as our good financial standing, our effectiveness as well as others, and customer-related indicators stay as positive as they are now. (TMT member)

At the moment of the interviews, a key concern of organizational strategy was to use the scorecard to measure and increase the competence and overall work performance of its personnel. This was also the main reason that many middle managers and operating personnel had initially welcomed the new system and committed to following this new approach in strategic management. However, when in place, the new approach was a grave disappointment for many organizational members. One of the key problems was that the balanced scorecard discourse was seen as alien and inaccessible to the lay personnel:

The problem is that the strategy specifications have been written from an organization-level viewpoint. When they are brought to the department level just like that, many problems emerge. (department head)

This system was also seen as very constraining. A particular problem was finding a measure to indicate the extensive workload of specific personnel: 
My team members feel bad because despite their requests, we can not find the kinds of measures that would enable us to show that we have too much work on our hands. This will not happen until somebody literally collapses under the workload. (team leader)

With the introduction of a new technology, the organization's strategy process thus became a measurement assignment where people were treated as objects and were not given opportunities to influence the key decisions. As a team leader put it:

You need to come up with all sorts of measures these days. You start reviewing how high somebody jumps and how this affects and all that, and maybe this intensifies our effectiveness. But, the human factor is forgotten. (team leader)

Vignette 5 illustrates tendencies that characterized several of our case organizations. The strategy process was typically conceptualized as a system driven by a specific predefined logic. In this discourse, organizational members were frequently assigned very specific but limited roles, to the extent that they were often seen as "resources" for the system rather than subjects involved in making decisions. This was less of a problem for top managers who had been involved in selecting the specific approach or system and defining the essential starting points. In fact, top management members were frequently the active spokespersons of specific technologies. However, the lower-level personnel experienced these systems as limiting their degrees of freedom - in particular, in discussion concerning common goals. In cases such as Vignette 5, it seems that tools had turned into control devices. In these cases, technologization resembled "programming" (Foucault 1977), which reduces individuals into objects to be governed.

\section{Discourses Promoting Participation}

Self-Actualization. Self-actualization is a socio-psychological process in which one seeks to find meaning in life and to develop oneself through enhancing experiences (Rogers 1995). We define self-actualization here as a discourse that focuses attention on the ability of people as individuals to outline and define objectives for themselves in strategy 
work. In some of our case organizations, self-actualization played a key role in strategy process. This was the case especially in Organization 11 (Vignette 6).

Vignette 6. Strategy as collective mapping.

Organization 11, a governmental office consisting mainly of expert personnel, had relatively few participation problems in its strategy process. Communication played a central role in the strategy process, both in disseminating information about organizational decisionmaking and in creating an informal discussion atmosphere. In fact, "initiative" and "openness" were the key terms used:

Anybody here can get an appointment with the CEOif they want to share an idea. (technical inspector)

In many ways, strategy was seen as a collective search for meaning in this organization. Typically, both top managers and operating personnel portrayed strategy as a resource for organization members, useful for making sense of their work in a larger context. In their strategy discourse, the focus was very much on individual reflection on how their specific interests and goals would or would not fit the more overall strategy of the organization. This is how people in this organization explained the essence of their strategy work:

We need to come up with the right answers ourselves. (team leader)

In this organization, we have basically the same goals but everybody makes their own interpretation of how they go about implementing those goals ... The direction top management has set for us is a positive force, as it portrays an organization focused on its members and constantly developing. (technical inspector)

Self-actualization portrays strategy as a search for deeper meaning in the organizational activities. Typically, this involved language describing strategy work as a collective "journey" or a process of collective "mapping," as Vignette 6 illustrates. Importantly, in this kind of discourse, strategy could only be found through in-depth reflection concerning the identity of the organization and one's role in it. Self-actualization occasionally involved language emphasizing the importance of "visions" or "missions," as in mystification. However, in these organizations, the focus was more on the processes 
of how and why specific missions or visions were "found" or "created," rather than on the final outcome.

In this kind of discourse, it was not only top management that was seen as responsible for defining the strategies; strategy was rather seen as a process open to all people in the organization. The process of discovering objectives together was often seen as more important than any final definition of joint aims. Strategy was also at times closely linked to deeper-level personal reflection concerning one's role, identity, and future in the organization. Frequently, active participants in strategy work were portrayed as "critical seekers."

The case organizations differed greatly as to how far the ideal of personal freedom of interpretation was pursued. In some cases, like Organization 11 (the vignette above), this kind of approach had become an inherent part of their strategy work. However, in other organizations, some people tried to advance self-actualization precisely as a counterforce to impeding practices. This is how a manager of Organization 3 characterized her efforts to encourage critical thinking within her organization:

I tend to use Alice in Wonderland as an example. I don't know if you have ever heard this one. About how she walks in the woods and gets lost. And then there in the tree you have the Cheshire Cat. And Alice asks for the right direction. And then the cat grins and says that the right direction depends on where you are and where you want to go. (TMT member)

Dialogization. Whereas self-actualization concentrates on the ideal of emancipation, participation can also be promoted through an integration of top-down and bottom-up approaches. By paying attention to the roles and rights of various groups of people to participate in decision making and negotiation, the dialogical view reflects the ideal of organized social dialogue of Habermas (1981). In strategy research, this kind of a process has been described as particularly beneficial for contemporary organizations (Westley 1990, Barry and Elmes 1997, Floyd and Wooldridge 2000). Such dialogical discourse played an important role in several of our case organizations but was particularly strong in Organization 4 (see Vignette 7). 


\section{Vignette 7. Top down, bottom up.}

In Organization 4, a multinational financial organization, the strategy process was characterized by a dialectic of top-down and bottom-up approaches. The organization had put in place a detailed strategy process where strategic plans, prepared by the top management, were transformed into operational plans by the middle managers and operating personnel in the field offices, which were again sent upward to be processed by the top management team. In their strategy discourse, the right of top management to provide overall guidelines was not questioned as long as these were seen as a meaningful basis for further planning:

Frames are always given to teams who work them into action plans which the team leaders then summarize and send back to top management. (team leader in a field office)

Strategy was thus seen as a collective endeavor. In fact, essential in their discourse was the inclusion of all relevant people in this process. This was clearly indicated in the official strategy process documents where themes such as "learning from one another" and "supporting each other" were given a central role. As a middle manager put it:

All the targets intended for my office for the next year are discussed with me before they are finalized. I too discuss the targets with my team members and look for their input. It is important that people can participate in planning. The worst thing that can happen is being hit on the head by targets you have never heard of. (field office manager)

In fact, a lack of participation was generally portrayed as a serious violation of the very idea of effective strategizing, as explained by a customer service clerk:

Yes, I do feel that I am qualified to participate in our strategy process. My superior is certainly not qualified to do our action plan alone. (customer service clerk in a field office)

This kind of strategy discourse represents a pragmatic way of allowing for participation and different views. Interestingly, in most of our cases involving strong dialogical 
elements, the authority position of top management was not challenged. On the contrary, it was often taken for granted that corporate management would play a central role in

outlining the overall objectives. However, at the same time neither was the right of the organizational members at various levels to participate in strategy work questioned. In fact, it was most often seen as a requirement for effective collective decision making. In some cases, dialogical elements had become an institutionalized part of organizational decision making. However, in many cases, such dialogue was not reality but something that specific persons spoke for to promote participation.

Concretization. Concretization is a pragmatic discourse that seeks to establish clear processes and practices in and through strategizing to ensure meaningful social and organizational action. This kind of facilitative discipline is needed to create a sense of "ontological security" for the people involved in strategy work (Giddens 1984, Mantere 2005). Concretization can thus be seen as a social grounding upon which individuals are able to find meaningful strategic roles. However, concretization also serves to demystify ambiguous and vague practices that often impede participation. It can thus represent a counterdiscourse to mystification. Organization 12 (Vignette 8) provides an illustrative example of such concretization discourse.

\section{Vignette 8. Strategy as a tool.}

Organization 12 is a municipal public health authority consisting of dozens of local clinics and other health offices, controlled by a central office under the city administration. Its current strategy had been crafted in cooperation with its stakeholders and had wideranging support throughout the organization. However, its further refinement and implementation challenged the practitioners in multiple ways. Interestingly, in this organization, strategy was increasingly seen as a tool for the people working at different levels of the organization. On the one hand, it was seen as a "structure" or "frame" that would guide future decision making as well as operative activities: 
[I see strategy as] a structure for activities, a frame of objectives, giving direction to activities. Sometimes our strategies involve rather detailed issues; sometimes you build a lot of things around this structure. (chief nurse in a public health clinic)

On the other hand, continuous work to make the strategic ideas and guidelines concrete and transparent was deemed crucial. This included a constant specification of various kinds of action plans in different parts of the organization. Such specifications did not "arrive" from the upper echelons, but were actively "constructed" or "crafted" by practitioners at all levels. In fact, new rules and procedures were often developed by the people engaged in the activities in question. In this sense, strategizing was seen as everyone's right and responsibility. The following is a typical example of how these people were dealing with difficult issues:

Immigration brings in new challenges. How do we deal with the circumcision of girls [A major issue for the organization], for instance? [Name withheld], who is a nurse practitioner in a unit specializing in immigrants, is in the process of crafting a set of guidelines. I am looking forward to seeing those [guidelines]. (nurse in a public health clinic)

Characteristic of concretization discourse was portrayal of strategy as an inherent, almost mundane part of organizational decision making. Strategy was often depicted as a process of constant "construction" rather than something "given" to the organization. Accordingly, the focus was on a continuous specification of rules and procedures. In a way, concretization can be seen as a radical discourse discarding the traditional ideals related to "grand" strategies. However, as Vignette 8 shows, concretization does not have to challenge the role of top managers as key strategists as long as strategy work produces meaningful results for the organization. Nevertheless, concretization implies that all those involved in key activities have an important role as "strategists" in the areas for which they were responsible. In this sense, concretization involves collective and distributive agency that is fundamentally different from the view advocated in conventional strategy research (for similar reflections on agency, see Jarzabkowski 2005, Chia and Holt 2006). 
By so doing, concretization works as a powerful discourse promoting organizationwide participation in strategy.

Organization 12 (Vignette 8 ) is a rare example of an organization where this kind of approach had become the dominant view on strategy. In several other cases, concretization served more as a call for a change of the current state of affairs. For instance, in Organizations 1 and 2 which were characterized by mystification, several interviewees called for the concretization of the abstract visions and the processes through which these visions were developed and put into practice. Such practices were seen as crucial to being able to advance "real participation in" and "commitment to" strategy work.

\section{Discussion}

In our analysis, we have focused on two interrelated questions: What kinds of discourses impede participation in strategy processes? and What kinds of discourses can promote more widespread participation? As a result, we have identified six widely used discourses, the main characteristics of which are summarized in Table 3. 
Table 3. Discourses impeding and promoting participation

\begin{tabular}{|c|c|c|c|c|}
\hline Discourses & $\begin{array}{l}\text { Conception of strategy } \\
\text { process }\end{array}$ & Subject positions & $\begin{array}{l}\text { Linkage to other social } \\
\text { practices }\end{array}$ & Effect on participation \\
\hline Mystification & $\begin{array}{l}\text { Strategy process is driven by } \\
\text { visions, missions and other } \\
\text { strategy statements that } \\
\text { provide the basis for } \\
\text { organizational activity. } \\
\text { These strategies are normally } \\
\text { not to be questioned or } \\
\text { criticized. }\end{array}$ & $\begin{array}{l}\text { Top managers are given a central } \\
\text { role as leaders defining the key } \\
\text { strategies. } \\
\text { This often involves 'preaching' of } \\
\text { the strategies to other } \\
\text { organizational members (pastoral } \\
\text { power). } \\
\text { The role of the other } \\
\text { organizational members is to } \\
\text { follow the strategies and leaders, } \\
\text { but not to question the legitimacy } \\
\text { of the key ideas or the power } \\
\text { position of the leaders. }\end{array}$ & $\begin{array}{l}\text { Strategies are often crafted } \\
\text { in closed workshops. } \\
\text { Access to information is } \\
\text { restricted. } \\
\text { Use of special experts (e.g. } \\
\text { consultants). }\end{array}$ & $\begin{array}{l}\text { The exclusive right of top } \\
\text { managers to define strategies } \\
\text { and withhold information is } \\
\text { legitimated. } \\
\text { Other organizational } \\
\text { members can participate } \\
\text { effectively only in the } \\
\text { implementation of the } \\
\text { strategies. }\end{array}$ \\
\hline Disciplining & $\begin{array}{l}\text { Strategy is linked to effective } \\
\text { organizational discipline and } \\
\text { command structures. } \\
\text { Strategizing is usually seen } \\
\text { exclusively as top } \\
\text { management activity. }\end{array}$ & $\begin{array}{l}\text { Top managers are seen as the key } \\
\text { strategists. } \\
\text { This often involves 'responsibility' } \\
\text { but also heroification. } \\
\text { The role of the others is to follow } \\
\text { the guidelines and orders coming } \\
\text { from the top. } \\
\text { Disobedience is punished. }\end{array}$ & $\begin{array}{l}\text { Strategy work is closely } \\
\text { linked to organizational } \\
\text { control mechanisms. } \\
\text { Access to information is } \\
\text { restricted. }\end{array}$ & $\begin{array}{l}\text { Top managers' key role in } \\
\text { strategizing is legitimated } \\
\text { and naturalized. } \\
\text { Other organizational } \\
\text { members can only participate } \\
\text { in ways defined by their } \\
\text { superiors. }\end{array}$ \\
\hline Technologization & $\begin{array}{l}\text { Strategy process is driven by } \\
\text { a specific system. } \\
\text { The system provides the } \\
\text { rules to be followed. }\end{array}$ & $\begin{array}{l}\text { Specific people }- \text { usually top } \\
\text { managers }- \text { define the systems to } \\
\text { be used. } \\
\text { Organizational members are to } \\
\text { follow the system. } \\
\text { Specific actors have expert power. }\end{array}$ & $\begin{array}{l}\text { Strategy work is closely } \\
\text { linked to concrete systems } \\
\text { and technologies. } \\
\text { Access to information is } \\
\text { controlled. }\end{array}$ & $\begin{array}{l}\text { Legitimates the use of } \\
\text { specific systems, often } \\
\text { effectively limiting the } \\
\text { ability to bring up new } \\
\text { perspectives or issues. }\end{array}$ \\
\hline Self-actualization & $\begin{array}{l}\text { Strategy process is about } \\
\text { finding meaning in } \\
\text { organizational activities. } \\
\text { Ideally, this leads to } \\
\text { emancipation at individual } \\
\text { and organizational levels. }\end{array}$ & $\begin{array}{l}\text { All organizational members can in } \\
\text { principle participate in } \\
\text { strategizing. }\end{array}$ & $\begin{array}{l}\text { Strategy work is linked to } \\
\text { micro (unit- or group-) - } \\
\text { level strategy workshops } \\
\text { and meetings. }\end{array}$ & $\begin{array}{l}\text { Legitimates separate group } \\
\text { and individual level } \\
\text { strategizing efforts and even } \\
\text { conflicting ideas. }\end{array}$ \\
\hline
\end{tabular}




\begin{tabular}{|c|c|c|c|c|}
\hline Dialogization & $\begin{array}{l}\text { Strategy process involves } \\
\text { dialectics between top down } \\
\text { and bottom up processes. } \\
\text { Ideally, this involves a } \\
\text { constructive dialogue } \\
\text { between different groups. }\end{array}$ & $\begin{array}{l}\text { The role of top managers as key } \\
\text { strategists is not questioned. } \\
\text { All actors that have a vested } \\
\text { interest are to participate in } \\
\text { strategy processes. }\end{array}$ & $\begin{array}{l}\text { Strategy } \\
\text { concrete is linked to } \\
\text { processes negotiation } \\
\text { various internal anvolving } \\
\text { external stakeholders. }\end{array}$ & $\begin{array}{l}\text { Legitimates top managers' } \\
\text { special status as key } \\
\text { strategists but not } \\
\text { independently of other } \\
\text { groups. } \\
\text { Helps to give voice to other } \\
\text { organizational members. }\end{array}$ \\
\hline Concretization & $\begin{array}{l}\text { Strategy process is seen as a } \\
\text { natural, almost mundane part } \\
\text { of organizational decision- } \\
\text { making. } \\
\text { Effective } \\
\text { requires concrete and } \\
\text { transparent rules and } \\
\text { practices. }\end{array}$ & $\begin{array}{l}\text { The role of top managers as key } \\
\text { strategists is not questioned but } \\
\text { expected to follow joint rules. } \\
\text { Other organizational actors are to } \\
\text { participate as specified by the joint } \\
\text { rules. }\end{array}$ & $\begin{array}{l}\text { Strategizing is } \\
\text { linked to rimately } \\
\text { organizational } \\
\text { making. }\end{array}$ & $\begin{array}{l}\text { Call for clear-cut and } \\
\text { transparent rules helps to } \\
\text { demystify strategizing and } \\
\text { legitimate wide participation. }\end{array}$ \\
\hline
\end{tabular}


These discourses are key to the reproduction of fundamentally different conceptions of strategy process in our case organizations. This involves the (re)construction of specific kinds of subject positions for the actors involved. As a result, these discourses tend to legitimize particular modes of participation while delegitimating others. These discourses are not the only factors having an impact on actual participation or nonparticipation in our case organizations (e.g., Westley 1990, Floyd and Wooldridge 2000). Rather, they play an important role as a part of the organizational praxis (Whittington 2006): the widespread use of these discourses reproduces and legitimizes concrete participatory or nonparticipatory social and material practices in organizations.

These discursive effects are, however, usually subtle and often pass unnoticed in organizational interaction (Samra-Fredericks 2003, 2005). As our case analysis shows, taken-for-granted assumptions are easily legitimized and naturalized in organizations to the extent that it becomes very different to think or act otherwise. This is the very reason why we need to pay special attention to discourses when dealing with participation. These discourses are not arbitrary but reflect central ideas in the body of knowledge (Knights and Morgan 1991) and praxis (Whittington 2006) around strategy. This applies particularly to mystification, disciplining, and technologization, which embody traditional views on strategy and strategizing. It is also not surprising that these discourses are easily reproduced in organizational settings, with constraining implications for participation. Self-actualization, dialogization, and concretization in turn present more recent conceptions about strategy, including ideas of more collective agency and distributed leadership. Our data also suggest that they are often used more consciously and intentionally to actively resist the traditional hegemonic discourses.

While many organizations are characterized by a particular discourse, these discourses can also coexist within the same organization. In fact, in several case organizations, self-actualization, dialogization, and concretization discourses were deliberately promoted to provide an alternative to the traditional discourses impeding participation. In this sense, strategy involves internal tensions around agency and identity. This is an important observation as most critical analyses of strategy discourse have so far paid little attention to the alternative discourses around strategy and strategizing (Knights and Morgan 1991, Hendry 2000, Samra-Fredericks 2003, Chia and Holt 2006). 
Acknowledging these discourses is, however, crucial to a better understanding of the complexities characterizing contemporary strategizing (Brown and Humphreys 2003, Laine and Vaara 2007).

This analysis shows how participation is linked to control-resistance dynamics in strategizing (Westley 1990, Levy et al. 2003, Balogun and Johnson 2005, Laine and Vaara 2007) and the role of discourse in these dynamics. In particular, our analysis demonstrates how managerial hegemony, subjugation, and resistance are played out with specific discourses. Mystification, disciplining, and technologization are the very means through which hegemony is established and legitimized in strategy work. It is often important for top managers to seek to establish more discipline and commitment to overall plans, and this is one of the fundamental reasons why top managers tend to promote traditional top-down driven approaches in strategizing. However, problems emerge if this leads to mystification, disciplining, technologization, or other discursive tendencies that reproduce managerial hegemony. The result is often a false belief in top management omnipotence and/or an exclusion of middle managers and other organizational members from organizational strategizing - even in situations when they would have a great deal to offer.

Actual modes of participation also depend on the consent or resistance of others in organizational hierarchy (see also Westley 1990, Levy et al. 2003). As our analysis shows, mystification, disciplining, and technologization tend to involve self-subjugation; and middle managers and other organizational members are willing to accept top-down control in organizational strategizing. In other words, a lack of participation easily prevails because the organizational actors do not see problems in top-down approaches that they are used to. In fact, many middle managers and operating personnel in our cases seemed to be happy to leave strategizing to top managers and not be involved. Such selfsubjugation may not always be perceived as a grave problem, but it does limit the insights fed into strategic planning and discourage active strategizing.

However, organizational members may also resist managerial hegemony and exclusive modes of participation. As is vividly shown in our first three vignettes, this can involve distancing and cynical attitudes. The problem is that while such resistance does not legitimize managerial hegemony, it does reproduce nonparticipation. That is, the 
cynical managers or organizational members easily become sidelined in strategy work and reproduce such exclusion by their own resistance. Their cynical attitudes may also have broader implications in undermining the legitimacy of any strategy process or approach to strategy. This is a significant observation as it helps us to understand how hegemonic strategy processes may become self-destructive in contexts calling for wide organizational support.

This is why it is so important to pay attention to "positive resistance" in the form of active promotion of alternative forms of strategy work. As our analysis illustrates, selfactualization, dialogization, and concretization are discourses that promote active engagement rather than passive resistance or withdrawal from strategy work. This is not to say that it would be easy to change nonparticipative approaches to active participation in any organization, but that such alternative discourses can provide effective means for resistance against hegemony and exclusion within the strategy discourse and praxis.

In our analysis, we have emphasized that discourses are not abstract entities that would exist independently of other social reality. This is important to fully comprehend the ever-pervasive but poorly understood role of discourse in strategizing. On the one hand, our analysis shows that discourses are firmly linked with other social and material practices. As Table 3 illustrates, the ways in which information is spread, meetings and workshops are organized, technologies are used, or control is exercised are the very practices that discourses can reproduce or legitimize. On the other hand, discourses themselves are maintained in social interaction. This means that we should be very conscious of the ways in which we think and talk about strategy. The concepts we use, the metaphors we employ, the jokes we tell, and the words we use in persuasion and convincing are not merely "rhetoric," but are intimately linked to the ways in which strategy and strategy processes are socially constructed.

Our analysis involves some serious limitations. First, it has not been our intention to claim evidence of a strong causal relationship between specific discursive acts and harmful or beneficial participation. We rather argue for the association of discourse and participation in our cases. This is not to undermine the performative effects of discourse, but to underline that they are context specific and subtle. Therefore, we have systematically focused on the central role of discourse in the reproduction and 
legitimation of participatory or nonparticipatory conceptions of strategy work. Second, it should be noted that our material does not represent "naturally occurring talk" (e.g., Potter and Wetherell 1987), which could be seen as the ideal basis for organizational discourse analysis. However, our analysis is based on extensive interview, documentary, and other data gathered in interaction with the representatives of these organizations. These multiple sources of data provided us with an opportunity to identify systematic discursive patterns in our case organizations and triangulate our findings (Denzin 1970).

Third, related to the previous issue, researchers' interventions may create interactional dynamics that lead to the reproduction of particular kinds of discourses. For example, one is likely to portray strategy processes in different ways depending on the interview setting. In our case, for example, the interview situation may have produced more "official" and "technocratic" language than more informal encounters. Nevertheless, the extensive number of the interviews and the ability to compare the interview material with other sources of data such as official strategy documents should alleviate these concerns. Fourth, the language issue should be taken seriously in discourse analysis. In practice, we have conducted our analysis in Finnish but translated both our codings and quotations into English. This has not been unproblematic as some meanings are unavoidably lost and others created in the process of translation. To ensure the quality of the translations, we have also consulted a translation specialist who is a native English speaker but fluent in Finnish. Fifth, a further concern relates to the generalizability of our research findings. When interpreting the case-specific patterns, one should be very conscious of the cultural setting in question. However, in our analysis, we have not sought universal patterns but rather intended to generate theory out of a data set of a particular kind. In short, we have aimed at analytical generalizations (Yin 1989, Tsoukas 1989) about the discourses impeding or promoting participation in strategy processes.

\section{Conclusion}

While a lack of participation is not always a problem in organizations, it is widely acknowledged that a lack of engagement often tends to decrease the quality of strategic planning and create various kinds of problems for the implementation of strategic plans 
(Westley 1990, Floyd and Wooldridge 2000, Balogun and Johnson 2004, Laine and Vaara 2007). We have argued that to better understand some of the most fundamental reasons why a lack of participation often characterizes organizational strategizing, we must examine the ways in which managers and other organizational members make sense of and give sense to strategy process. For this purpose, we have outlined a critical discursive perspective and identified discourses that seem to systematically impede or promote participation. We believe that this is an important contribution as it furthers our understanding of how nonparticipatory conceptions of strategy work are reproduced and legitimized in organizational contexts. This analysis also helps us to see what kinds of discourses can be mobilized to promote participation.

This analysis also aids to advance our overall understanding of strategy discourses. To date, studies taking a discursive perspective on strategy have been theoretically oriented, including few empirical analyses (e.g., Samra-Fredericks 2003, Laine and Vaara 2007). Moreover, most of these critical analyses have mainly focused on the hegemonic aspects of traditional strategy discourses without explicating the emancipatory potential residing in alternative discourses (Knights and Morgan 1991, Levy et al. 2003). By bringing up both kinds of discourses, our analysis helps us to understand the internal tensions in strategy that easily pass unnoticed. In our view, these tensions are examples of competing paradigms (Mumby 2004, 2005) that characterize the strategy field and should be taken seriously in research as well as practice.

This analysis focusing on discourses impeding and promoting participation can also be seen as an effort to further our understanding of the linkage between strategy discourses and other organizational practices. The discourses revealed in our analysis are not only theoretical ideas or disconnected examples of strategy talk, but also systematic ways of representing strategizing (Whittington 2006). Singling out the discursive elements is very important as the role of discourse as part of other organizational practices has so far remained elusive (Hendry 2000, Jarzabkowski 2005, Chia and Holt 2006, Whittington 2006). Our analysis underscores that discourses both reflect prevailing organizational praxis and serve to legitimize or delegitimize particular practices. It is this latter legitimation function that we should be especially conscious of when studying strategy processes and problems in them. 
This was an exploratory study and should be followed and complemented by other analyses. Future studies could be based on longitudinal case designs and focus on the concrete causal processes and mechanisms linking specific discourses and participative or nonparticipative behaviors in strategizing. Such analysis could draw from existing studies of sensemaking (Balogun and Johnson 2004, 2005) but extend the sensemaking framework by explicating the role of discourse among other practices impeding or promoting participation. Such analyses would help us to better understand the role of actors such as middle managers in promoting or resisting management hegemony and supporting or repressing inclusion in strategy work. Another important study would be to examine more closely how specific social practices such as rituals related to strategy work are legitimized and naturalized. Future studies should also focus more on concrete microlevel interaction. For instance, conversation analysis would provide insights into ways in which specific discourses are used in concrete social strategizing situations (Samra-Fredericks 2003, 2005). Other analyses could go further in examining specific texts and the microlevel linguistic processes and functions (Hodge and Coronado 2006). Still other studies could take a narrative perspective and focus on "authorship" and its relation to the discursive construction of identity (Vaara 2002) and the alternative narratives that may characterize strategizing (Brown and Humphreys 2003). Whilst our analysis has focused on discourses impeding or promoting participation, future studies could take a step further and examine how such discourse use may vary depending on the social position and background (e.g., education, age, gender) as well as hierarchical position of the people involved. Of special interest would be to analyze cynicism, irony, and other forms of resistance in more detail. Future studies could also analyze discourse use in the strategy literature or in the media (Whittington et al. 2003). This would allow us to better understand the ways in which particular conceptions of strategy are promoted or challenged in society at large.

Finally, this study has clear practical implications - not only for managers but also for others involved in the "strategy industry" (Whittington 2006). Most important, this analysis helps to show how traditional conceptions of strategy easily prevail in organizations, often effectively impeding widespread participation. The crucial point is that these conceptions do not just lie in organizations, but are spread by institutional 
actors such as strategy experts and consultants, business schools, and the business press (Whittington 2006) — often in ways that pass unnoticed. Paying attention to problematic discourses such as mystification, disciplining, and technologization is a first step toward changing the state of affairs. Another step can then be the promotion of alternative discourses such as self-actualization, dialogization, or concretization. This is not to say that all problems concerning participation would be solved with such rhetoric, but to emphasize that genuine widespread participation requires reconsideration of the ways in which we all think and talk about strategy.

\section{Acknowledgments}

This is a fully coauthored article. Authors are listed in alphabetical order for convenience. The authors thank Senior Editor Deborah Dougherty and three anonymous reviewers who played a crucial role in the development of this paper. The authors also thank Jeff Hearn, David Miller, Dalvir Samra- Fredericks, and John Sillince for helpful commentary and critique; and Petri Aaltonen, Heini Ikävalko, and Mari Ventä for an important contribution to data collection. The authors are grateful for the financial support of the Finnish Work Environment Fund. 


\section{References}

Alvesson, M., D. Kärreman. 2000. Varieties of discourse: On the study of organizations through discourse analysis. Human Relations 53(9) 1125-1251.

Balogun, J., G. Johnson. 2004. Organizational restructuring: The impact of middle manager sensemaking. Acad. Management Rev. 47(4) 523-549.

Balogun, J., G. Johnson. 2005. From intended strategies to unintended outcomes: The impact of change recipient sensemaking. Organ. Stud. 26(11) 1573-1601.

Barry, D., M. Elmes. 1997. Strategy retold: Toward a narrative view of strategic discourse. Acad. Management Rev. 22(2) 429-452.

Bourgeois, L. J., D. R. Brodwin. 1984. Strategic implementation: Five approaches to an elusive phenomenon. Strategic Management J. 5(3) 241-264.

Brown, A. D., M. Humphreys. 2003. Epic and tragic tales: Making sense of change. $J$. Appl. Behavioral Sci. 39(2) 121-144.

Burgelman, R. A. 1983. A process model of internal corporate venturing in the diversified firm. Admin. Sci. Quart. 28(2) 223-244.

Chakravarthy, B. S., Y. Doz. 1992. Strategy process research: Focusing on corporate selfrenewal. Strategic Management J. 13 5-14.

Chia, R., R. Holt. 2006. Strategy as practical coping: A Heideggerian perspective. Organ. Stud. 27(5) 635-655.

Collins, D. 1997. The ethical superiority and inevitability of participatory management as an organizational system. Organ. Sci. 8(5) 489-506. 
Davies, B., R. Harré. 1990. Positioning: The discursive production of selves. J. Theory Soc. Behavior 20(1) 43-63.

Denzin, N. 1970. Strategies of multiple triangulation. N. Denzin, ed. The Research Act in Sociology: A Theoretical Introduction to Sociological Method. McGraw-Hill, New York, 297-313.

Dougherty, D. 2004. Organizing practices in services: Capturing practice-based knowledge for innovation. Strategic Organ. 2(1) 35-64.

Dunford, R., D. Jones. 2000. Narrative in strategic change. Human Relations 53(9) 12071226.

Fairclough, N. 2003. Analysing Discourse: Textual Analysis for Social Research. Routledge, London, UK.

Fairclough, N. 2005. Discourse analysis in organization studies: The case for critical realism. Organ. Stud. 26(6) 915-939.

Fairclough, N., R. Wodak. 1997. Critical discourse analysis. T. Van Dijk, ed. Discourse as Social Interaction. Sage, London, UK, 258-284.

Floyd, S. W., P. J. Lane. 2000. Strategizing throughout the organization: Managing role conflict in strategic renewal. Acad. Management Rev. 25(1) 154-177.

Floyd, S. W., B. Wooldridge. 2000. Building Strategy From the Middle. Sage, London, UK.

Foucault, M. 1977. Discipline and Punish. The Birth of the Prison.Random House, New York. 
Foucault, M. 1982. Subject and power. H. Dreyfus, P. Rabinow, eds. Michel Foucault: Beyond Hermeneutics and Structuralism. Harvester, Brighton, UK, 208-226.

Foucault, M. 1994. Power: Essential Works of Foucault, Vol. III, 1954-1984. J. D. Faubion, ed. The New Press, New York.

Giddens, A. 1984. The Constitution of Society. University of California Press, Berkeley, CA.

Gioia, D. A., K. Chittipeddi. 1991. Sensemaking and sensegiving in strategic change initiation. Strategic Management J. 12(6) 433-448.

Gioia, D. A., J. B. Thomas, S. M. Clark, K. Chittipeddi. 1994. Symbolism and strategic change in academia: The dynamics of sensemaking and influence. Organ. Sci. 5(3) 363383.

Grandy, G., A. J. Mills. 2004. Strategy as simulacra? A radical reflexive look at the discipline and practice of strategy. J. Management Stud. 41(7) 1153-1170.

Grant, D., C. Hardy, C. Oswick, L. Putnam, eds. 2004. Organizational Discourse. Sage, London, UK.

Guth, W. D., I. C. MacMillan. 1986. Strategy implementation versus middle management self-interest. Strategic Management J. 7(4) 313-327.

Habermas, J. 1981. The Theory of Communicative Action. Beacon Press, Boston, MA.

Hardy, C., N. Phillips. 2004. Discourse and power. D. Grant, C. Hardy, C. Oswick, L. L. Putnam, eds. The Sage Handbook of Organizational Discourse. Sage, London, UK, 299316. 
Hardy, C., I. Palmer, N. Phillips. 2000. Discourse as a strategic resource. Human Relations 53(9) 1227-1248.

Hardy, C., D. Grant, T. Keenoy, C. Oswick, N. Phillips, eds. 2004.

Special issue on "Organizational Discourse." Organ. Stud. 25(1). Hart, S. L. 1992. An integrative framework for strategy-making processes. Acad. Management Rev. 17(2) $327-351$.

Heidegger, M. 1977. The Question Concerning Technology and Other Essays. Harper and Row, New York.

Hendry, J. 2000. Strategic decision making, discourse, and strategy as social practice. J. Management Stud. 37(7) 955-977.

Hodge, B., G. Coronado. 2006. Mexico Inc.? Discourse analysis and the triumph of managerialism. Organization 13(4) 529-547.

Jarzabkowski, P. 2004. Strategy as practice: Recursiveness, adaptation and practices-inuse. Organ. Stud. 25(4) 529-560.

Jarzabkowski, P. 2005. Strategy as Practice: An Activity-Based Approach. Sage, London, UK.

Jarzabkowski, P., J. Balogun, D. Seidl. 2007. Strategizing: The challenges of a practice perspective. Human Relations 60(1) 5-27.

Jick, T. D. 1979. Mixing qualitative and quantitative methods: Triangulation in action. Admin. Sci. Quart. 24(4) 602-611.

Johnson, G., L. Melin, R. Whittington. 2003. Special issue on micro strategy and strategizing: Towards an activity-based view. J. Management Stud. 40(1) 3-22. 
Ketokivi, M., X. Castañer. 2004. Strategic planning as an integrative device. Admin. Sci. Quart. 49(3) 337-365.

Kim, W. C., R. Mauborgne. 1998. Procedural justice, strategic decision making and the knowledge economy. Strategic Management J. 19(4) 323-339.

Klein, K. J., J. S. Sorra. 1996. The challenge of innovation implementation. Acad. Management Rev. 21(4) 1055-1061.

Knights, D., G. Morgan. 1991. Corporate strategy, organizations, and subjectivity: A critique. Organ. Stud. 12(2) 251-273.

Korsgaard, M. A., D. M. Schweiger, H. J. Sapienza. 1995. Building commitment, attachment, and trust in strategic decisions. Acad. Management J. 38(1) 60-85.

Laine, P., E. Vaara. 2007. Struggling over subjectivity: A discursive analysis of strategic development in an engineering group. Human Relations 60(1) 29-58.

Langley, A. 1999. Strategies for theorizing from process data. Acad. Management Rev. 24(4) 691-710.

Levy, D. L., M. Alvesson, H. Willmott. 2003. Critical approaches to strategic management. M. Alvesson, H. Willmott, eds. Studying Management Critically. Sage, London, UK, 92-110.

Lilley, S. 2001. The language of strategy. R. Westwood, S. Linstead, eds. The Language of Organization. Sage, London, UK, 66-88.

Lovas, B., S. Ghoshal. 2000. Strategy as guided evolution. Strategic Management J. 21(9) 875-896. 
Maitlis, S., T. B. Lawrence. 2003. Orchestral manoeuvres in the dark: Understanding failure in organizational strategizing. J. Management Stud. 40(1) 109-139.

Mantere, S. 2003. Champion, citizen, cynic? Social positions in the strategy process. Doctoral dissertation, Helsinki University of Technology, Espoo, Finland.

Mantere, S. 2005. Strategic practices as enablers and disablers of championing activity. Strategic Organ. 3(2) 157-184. Marx, K. 1999. Das Kapital. Regnery Publishing, Washington, D.C.

Miles, R. E., C. C. Snow, A. D. Meyer, H. J. Coleman. 1978. Organizational strategy, structure and process. Acad. Management Rev. 3(3) 546-562.

Mintzberg, H. 1978. Patterns of strategy formation. Management Sci. 24(9) 934-948.

Mintzberg, H. 1994. The Rise and Fall of Strategic Planning. Free Press, New York.

Mintzberg, H., J. A. Waters. 1985. Of strategies, deliberate and emergent. Strategic Management J. 6(3) 257-272.

Mintzberg, H., J. Lampel, B. Ahlstrand. 1998. Strategy Safari: A Guided Tour Through The Wilds of Strategic Management. Free Press, New York.

Mumby, D. K. 2004. Discourse, power and ideology: Unpacking the critical approach. D. Grant, C. Hardy, C.

Oswick, L. Putnam, eds. The SAGE Handbook of Organizational Discourse. Sage, London, UK, 237-258. 
Mumby, D. K. 2005. Theorizing resistance in organizational studies. A dialectical approach. Management Comm. Quart. 19(1) 19-44.

Noda, T., J. L. Bower. 1996. Strategy making as iterated processes of resource allocation. Strategic Management J. 17(Summer) 159-192.

Nutt, P. C. 1987. Identifying and appraising how managers install strategy. Strategic Management J. 8(1) 1-14.

Nutt, P. C. 1989. Selecting tactics to implement strategic plans. Strategic Management J. 10 (2) 145-161.

Oakes, L., B. Townley, D. Cooper. 1998. Business planning as pedagogy: Language and control in a changing institutional field. Admin. Sci. Quart. 43(2) 257-292.

Pettigrew, A. M. 1973. The Politics of Organizational Decision-Making. Tavistock, London, UK.

Pettigrew, A. M. 1992. The character and significance of strategy process research. Strategic Management J. 13 5-16.

Phillips, N., C. Hardy. 2002. Discourse Analysis. Investigating Processes of Social Construction. Sage, Thousand Oaks, CA.

Potter, J., M. Wetherell. 1987. Discourse and Social Psychology. Sage, London, UK.

Rogers, C. 1995. On Becoming a Person: A Therapist's View of Psychotherapy. Houghton Mifflin, New York.

Sagie, A., M. Koslowsky. 2000. Participation and Empowerment in Organizations. Sage, London, UK. 
Samra-Fredericks, D. 2003. Strategizing as lived experience and strategists' everyday efforts to shape strategic direction. J. Management Stud. 40(1) 141-174.

Samra-Fredericks, D. 2004. Managerial elites making rhetorical and linguistic "moves" for a moving (emotional) display. Human Relations 57(9) 1103-1143.

Samra-Fredericks, D. 2005. Strategic practice, "discourse" and the everyday interactional constitution of "power effects." Organization 12(6) 803-841.

Silverman, D. 2000. Doing Qualitative Research. Sage, London, UK. Tsoukas, H. 1989. The validity of idiographic research explanations. Acad. Management Rev. 14(4) 551561.

Vaara, E. 2002. On the discursive construction of success/failure in narratives of postmerger integration. Organ. Stud. 23(2) 213-250.

Vaara, E., B. Kleymann, H. Seristö. 2004. Strategies as discursive constructions: The case of airline alliances. J. Management Stud. 41(1) 1-35.

van Dijk, T. 1997. Discourse Studies: A Multidisciplinary Introduction, Vols. 1 and 2. Sage, London, UK. van Dijk, T. A. 1998. Ideology: A Multidisciplinary Analysis. Sage, London, UK.

Westley, F. R. 1990. Middle managers and strategy: Microdynamics of inclusion. Strategic Management J. 11(5) 337-351.

Whittington, R. 1993. What is Strategy—And Does It Matter? Routledge, London, UK.

Whittington, R. 1996. Strategy as practice. Long Range Planning 29(5) 731-735. 
Whittington, R. 2006. Completing the practice turn in strategy research. Organ. Stud. $27(5) 613-634$.

Whittington, R., P. Jarzabkowski, M. Mayer, E. Mounoud, J. Nahapiet, L. Rouleau. 2003. Taking strategy seriously. Responsibility and reform for an important social practice. $J$. Management Inquiry 12(4) 396-409.

Wodak, R. 2004. Critical discourse analysis. C. Seale, J. F. Gubrium, D. Silverman, eds. Qualitative Research Practice. Sage, London, UK, 197-213.

Wodak, R., M. Meyer. 2002. Methods of Critical Discourse Analysis. Sage, London, UK.

Yin, R. 1989. Case Study Research, revised ed. Sage, London, UK. 